\title{
Analisis Faktor-Faktor Yang Mempengaruhi Manajemen Laba Dengan Profitabilitas Sebagai Variabel Moderating Pada Perusahaan Pertambangan Yang Terdaftar Di Bursa Efek Indonesia
}

\author{
Atikah Darayani Nasution, Idhar Yahya, H. B. Tarmizi \\ Program Studi Magister Ilmu Akuntansi, Universitas Sumatera Utara, Indonesia \\ Email corresponding author: atikahdarayaninst@gmail.com idharyahya@ gmail.com \\ Hasanb.tarmizi@gmail.com
}

\begin{abstract}
ABSTRAK
Penelitian ini dilakulan untuk mengetahui apakah asimetri informasi, leverage, audit tenure dan kepemilikan manajerial berpengaruh terhadap manajemen laba pada Perusahaan Pertambangan yang terdaftar di Bursa Efek Indonesia (BEI). Selain itu, penelitian ini juga bertujuan untuk mengetahui apakah profitabilitas dapat dijadikan sebagai variabel moderating dalam model penelitian. Penelitian ini merupakan penelitian assosiatif kausal. Berdasarkan teknik purposive sampling, maka jumlah sampel yang digunakan dalam penelitian ini adalah 9 Perusahaan Pertambangan yang terdaftar di Bursa Efek Indonesia (BEI) tahun 2008-2019, sehingga total observasi yang digunakan dalam penelitian ini adalah 108 data. Untuk teknik analisis data, penelitian ini menggunakan pendekatan Structural Equation Model (SEM) berbasis Partial Least Square (PLS) yang dijalankan dengan menggunakan bantuan software SmartPLS. Hasil yang ditemukan dalam penelitian ini menunjukkan bahwa asimetri informasi, audit tenure dan kepemilikan manajerial terbukti memiliki pengaruh yang positif dan signifikan terhadap manajemen laba. Sedangkan leverage memiliki pengaruh yang negatif dan signifikan. Sementara itu, hasil lainnya dalam penelitian ini menunjukkan bahwa profitabilitas hanya mampu memoderasi pengaruh leverage terhadap manajemen laba, sedangkan pada variabel independen lainnya tidak.
\end{abstract}

Kata kunci: asimetri informasi, leverage, audit tenure, kepemilikan manajerial dan manajemen laba.

\section{PENDAHULUAN}

Praktik manajemen laba terjadi karena pihak manajemen sebagai pengelola perusahaan lebih banyak mengetahui informasi internal dan prospek perusahaan di masa yang akan datang dibandingkan dengan pemilik perusahaan. Dengan pengetahuan informasi tersebut terkadang agent menyampaikan informasi kepada pemilik tidak sesuai dengan kondisi perusahaan yang sebenarnya, sehingga agent mendapatkan peluang untuk melakukan praktek manajemen laba demi memaksimalkan utilitasnya. Adanya fenomena manajemen laba tersebut dapat mengakibatkan pengungkapan yang menyesatkan, sehingga mengakibatkan terjadinya kesalahan pengambilan keputusan oleh pihak-pihak yang berkepentingan dengan perusahaan, khususnya pihak eksternal (Jatinungrum, 2000)

Bebarapa kasus atau skandal kecurangan yang terkait dengan manajemen laba terjadi pada PT Timah (Persero) Tbk. PT Timah (Persero) Tbk memberikan laporan keuangan fiktif pada semester-1 2015. Kegiatan laporan keuangan fiktif ini dilakukan guna menutupi kinerja keuangan PT Timah yang terus mengkhawatirkan. Contohnya adalah pada press release laporan keuangan semester-1 2015 yang mengatakan bahwa efisensi dan strategi yang telah membuahkan kinerja yang positif. Namun pada kenyataanya pada semester-1 2015 laba operasi rugi sebesar $\mathrm{Rp} 59$ miliar. 
Kasus manipulasi dan akuntansi yang melibatkan tiga perusahaan pertambangan yang termasuk dalam Grup Bakrie, yaitu PT. Kaltim Prima (KPC) dan PT. Arutmin Indonesia (Arutmin), serta induk perusahaan tersebut, yaitu PT. Bumi Resoucers Tbk (BUMI) yang terjadi pada tahun 2010. Indonesia Coruption Watch (ICW) melaporkan dugaan manipulasi laporan keuangan penjualan batubara oleh PT. Bumi Resources Tbk dan dua anak usahanya kepada Direktorat Jenderal Pajak. Rekayasa laporan penjualan tersebut diduga telah dilakukan sejak tahun 2003 sampai 2008 sehingga menyebabkan kerugian negara hingga mencapai US\$ 620,49 juta. Menurut hasil perhitungan ICW yang menggunakan data primer termasuk laporan yang telah di audit, laporan penjualan Bumi selama 2003 hingga 2008 lebih rendah US\$ 1,6 miliar dari yang sebenarnya. Hal ini menyebabkan kerugian negara dari kekurangan penerimaan. Dana Hasil Produksi Batubara (royalti) yang diperkirakan sebesar US\$ 142,18 juta (Wijaya, 2010).

Kasus manipulasi laporan keuangan juga pernah terjadi pada tahun 2009 menimpa perusahaan BUMN yaitu Waskita Karya yang melakukan kelebihan pencatatan laba bersih pada laporan keuangan 2004-2008 sekitar Rp 400 Miliar. Laba yang seharusnya masuk pembukuan tahun depan dicatat sebagai laba tahun lalu. Terbongkarnya kasus ini berawal pada saat pemeriksaan kembali neraca dalam rangka penerbitan saham perdana. Direktur menemukan pencatatan yang tidak sesuai.

Pada tahun 2019 kasus manipulasi laporan keuangan juga terjadi pada maskapai plat merah milik BUMN yaitu PT. Garuda Indonesia Tbk. Dalam laporan keuangan untuk tahun buku 2018, Garuda Indonesia Group membukukan laba bersih sebesar 809,85 ribu US Dollar. Angka tersebut meningkat tajam dibanding tahun 2017 yang menderita kerugian sebesar 216.5 juta US Dollar. Dua orang komisaris Garuda Indonesia menganggap laporan keuangan tahun 2018 tersebut tidak sesuai dengan Pernyataan Standar Akuntansi Keuangan (PSAK), mereka merasa keberatan dengan pengakuan pendapatan atas transaksi perjanjian kerja sama penyediaan layanan konektivitas antara PT. Mahata Aero Teknologi dan PT. Citilink Indonesia. Manajemen Garuda Indonesia mengakui pendapatan dari Mahata sebear 239.94 juta US Dollar, padahal uang tersebut masih dalam bentuk piutang namun diakui perusahaan masuk dalam pendapatan.

Fenomena kasus skandal keuangan pada laporan keuangan yang terjadi di dunia membuktikan bahwa masih kurangnya prinsip kejujuran dalam menghasilkan laporan keuangan yang berintegritas dan menyajikan informasi dalam laporan keuangan dengan kondisi sebenarnya. Dimana perusahaan membuat keputusan yang kurang tepat sehingga terjadi kecurangan dalam penyusunan laporan keuangan. Pihak manajemen perusahaan cenderung melakukan skandal karena berbagai faktor untuk menjaga perusahaan agar tetap berada pada kondisi yang baik sehingga tidak membuat para pemegang saham khawatir.

Asimetri informasi merupakan salah satu aspek pemicu timbulnya manajemen laba. Asimetri informasi adalah situasi yang muncul ketika satu pihak tidak memiliki pengetahuan tentang pihak lain yang terlibat dalam transaksi sehingga tidak mungkin untuk membuat keputusan yang akurat ketika melakukan transaksi dimana salah satu pihak yang terlibat tersebut memiliki keunggulan dan kelebihan informasi dibandingkan pihak lain (Scott, 2009).

Rasio leverage merupakan rasio yang terdapat pada laporan keuangan yang dapat mengetahui seberapa besar perusahaan dibiayai oleh hutang dengan kemampuan perusahaan yang digambarkan oleh modal, atau dapat juga menunjukan beberapa bagian aset yang digunakan untuk menjamin hutang (Nugroho, 2011). Leverage mempunyai hubungan dengan praktik manajemen laba, dimana investor akan melihat rasio leverage perusahaan yang terkecil karena rasio leverage mempengaruhi dampak resiko yang terjadi. Jadi semakin kecil rasio leverage semakin kecil resikonya, begitu juga sebaliknya.

Hal lain yang dapat mempengaruhi manajemen laba adalah audit tenure. Audit tenure merupakan lamanya masa perikatan audit dari Kantor Akuntan Publik (KAP) dalam 
memberikan jasa audit terhadap kliennya. Kekerabatan yang berlebihan itu dapat mengakibatkan keraguraguan atau kepuasan auditor untuk menghadapi tantangan sewajarnya, dengan demikian untuk mengurangi tingkat keragu-raguan diperlukan suatu audit yang efektif (Wijayanti, 2010).

Kepemilikan manajerial merupakan besarnya kepemilikan saham yang dimiliki oleh manajer. Dari sudut pandang teori akuntansi, manajemen laba sangat ditentukan oleh motivasi manajer perusahaan. Motivasi yang berbeda akan menghasilkan besaran manajemen laba yang berbeda, seperti antara manajer yang juga sekaligus sebagai pemegang saham dan manajer yang tidak sebagai pemegang saham. Sehingga dapat dikatakan bahwa bahwa persentase tertentu kepemilikan saham oleh pihak manajemen cenderung mempengaruhi tindakan manajemen laba (Gideon, 2005).

Profitabilitas menunjukkan kemampuan perusahaan menghasilkan laba. Profitabilitas digunakan sebagai indikator dalam menilai suatu perusahaan. Dalam kaitannya dengan manajemen laba, profitabilitas dapat mempengaruhi manajer untuk melakukan manajemen laba. Karena jika profitabilitas perusahaan rendah, umumnya manajer akan melakukan tindakan manajemen laba untuk menyelamatkan kinerjanya di hadapan pemilik. Hal ini berkaitan erat dengan usaha manajer untuk menampilkan performa terbaik dari perusahaan yang dipimpinnya (Gunawan et al., 2015)

\section{TINJAUAN PUSTAKA}

\section{Teori Keagenan (Agency Theory)}

Hubungan keagenan merupakan suatu kontrak dimana satu atau lebih orang (principal) melibatkan orang lain (agent) untuk melakukan beberapa layanan atas nama mereka dan kemudian mendelegasikan sebagian kewenangan pengambilan keputusan kepada agen tersebut. Dengan kata lain, para pemilik perusahaan atau pemegang saham menunjuk manajemen yang dimaksudkan untuk mengelola perusahaan yang dimilikinya ( Jensen \& Meckling, 1976). Masalah agensi disebabkan oleh adanya perbedaan kepentingan bahwa masalah agensi disebabkan oleh adanya perbedaan kepentingan dan asimetri informasi antara principal dan agent. Principal adalah pemegang saham atau investor, sedangkan agent adalah manajemen yang mengelola perusahaan atau manajer. Inti dari hubungan keagenan adalah adanya pemisahan fungsi antara kepemilikan di investor dan pengendalian di pihak manajemen.

\section{Teori Sinyal (Signaling Theory)}

Signaling theory merupakan tentang bagaimana seharusnya sebuah perusahaan memberikan sinyal kepada pengguna laporan keuangan. Sinyal ini berupa informasi apa yang sudah dilakukan oleh manajemen untuk merealisasikan keinginan pemilik. Sinyal dapat berupa promosi atau informasi lain yang menyatakan bahwa perusahaan tersebut lebih baik daripada perusahaan lain (Ratna \& Zuhrohtun, 2006)

\section{Manajemen Laba}

Manajemen laba merupakan sifat akuntansi yang banyak mengandung taksiran (estimasi), pertimbangan (judgment) dan sifat accrual membuka peluang untuk bisa mengatur laba (Yung \& Root, 2019). Manajemen laba diukur melalui discretionary accruals (DA) yang dihitung dengan cara menselisihkan total accruals (TA) dan non discretionary accruals (NDA). Dalam menghitung DA, digunakan Modified Jones Model, karena model ini dianggap lebih baik diantara model lain untuk mengukur manajemen laba sejalan dengan hasil penelitian (Dechow, 1995). Model perhitungannya sebagai berikut: 
1. Perhitungan total akrual dengan menggunakan pendekatan arus kas (cash flow apporoach)

$$
T A C_{i, t}=N I_{i, t}-O C F_{i, t}
$$

2. Mencari nilai koefisien dari regresi total akrual

$$
\frac{T A C_{i t}}{T A_{i t-1}}=\alpha_{1}\left(\frac{1}{T A_{i t-1}}\right)+\beta_{1}\left(\frac{\Delta R E V_{i t}-\Delta R E C_{i t}}{T A_{i t-1}}\right)+\beta_{2}\left(\frac{P P E_{t}}{T A_{t-1}}\right)+\varepsilon_{i t}
$$

3. Perhitungan discretionary accrual

$$
D A C=\frac{T A C}{T A_{i t-1}}-\left(\alpha_{1}\left(\frac{1}{T A_{i t-1}}\right)+\beta_{1}\left(\frac{\left(\Delta R E V_{i t}-\Delta R E C_{i t}\right.}{T A_{i t-1}}\right)+\beta_{2}\left(\frac{P P E_{i t}}{T A_{i t-1}}\right)\right)
$$

\section{Asimetri Informasi}

Asimetri Informasi dihitung diukur dengan menggunakan relative bid-ask spread, dimana asimetri informasi dilihat dari selisih harga ask dengan harga bid saham perusahaan atau selisih harga jual dan harga beli saham perusahaan selama satu tahun (Firdaus, 2013).

\section{Leverage}

$$
\text { Spread }=\frac{\text { ask price }- \text { bid price }}{(\text { ask price }+ \text { bid price }) / 2} \times 100 \%
$$

Leverage adalah rasio yang mengukur besarnya aset perusahaan yang dibiayai oleh hutang. Semakin tinggi rasio leverage maka semakin banyak asset yang didanai hutang oleh pihak kreditor, sehingga menunjukan resiko perusahaan dalam pelunasannya, hal ini dapat memicu terjadinya praktek manajemen laba. Pada penelitian ini pengukuran leverage dihitung dengan menggunakan rasio utang terhadap total aset (Agustia, 2013).

\section{Audit Tenure}

$$
\text { Leverage }=\frac{\text { Total Hutang }}{\text { Total Aset }}
$$

Audit Tenure diukur dengan cara menghitung jumlah tahun perikatan audit antara perusahaan dengan auditor. Apabila perikatan audit dilakukan oleh auditor dari KAP yang sama, maka tahun pertama perikatan dimulai dengan angka 1 dan ditambah dengan satu untuk tahun-tahun berikutnya. Informasi ini dilihat di laporan auditor independen selama beberapa tahun untuk memastikan lamanya auditor KAP yang mengaudit perusahaan tersebut.

\section{Kepemilikan Manajerial}

Kepemilikan manajerial adalah jumlah kepemilikan saham yang dimiliki oleh manajer. Dalam penelitian ini kepemilikan manajerial diukur dengan persentasekepemilikan saham oleh pihak manajemen terhadap total modal saham perusahaan.

$$
\text { Kepemilikan Manajerial }=\frac{\text { Jumlah Saham Manajemen }}{\text { Jumlah Saham yang Beredar }} \times 100 \%
$$

\section{Profitabilitas}

Profitabilitas adalah kemampuan perusahaan untuk memperoleh laba dari kegiatan bisnis yang dilakukan. Profitabilitas digunakan sebagai indikator dalam menilai suatu perusahaan. Dalam penelitian ini tingkat profitabilitas perusahaan diukur dengan menggunakan Return on Assets (ROA). Return on Assets menunjukkan kemampuan perusahaan menghasilkan laba dari aset yang dimiliki perusahaan.

$$
\text { Return On Asset }=\frac{\text { Earning After Tax }}{\text { Total Assets }}
$$


Adapun kerangka berfikir dalam penelitian ini dapat digambarkan sebagai berikut :

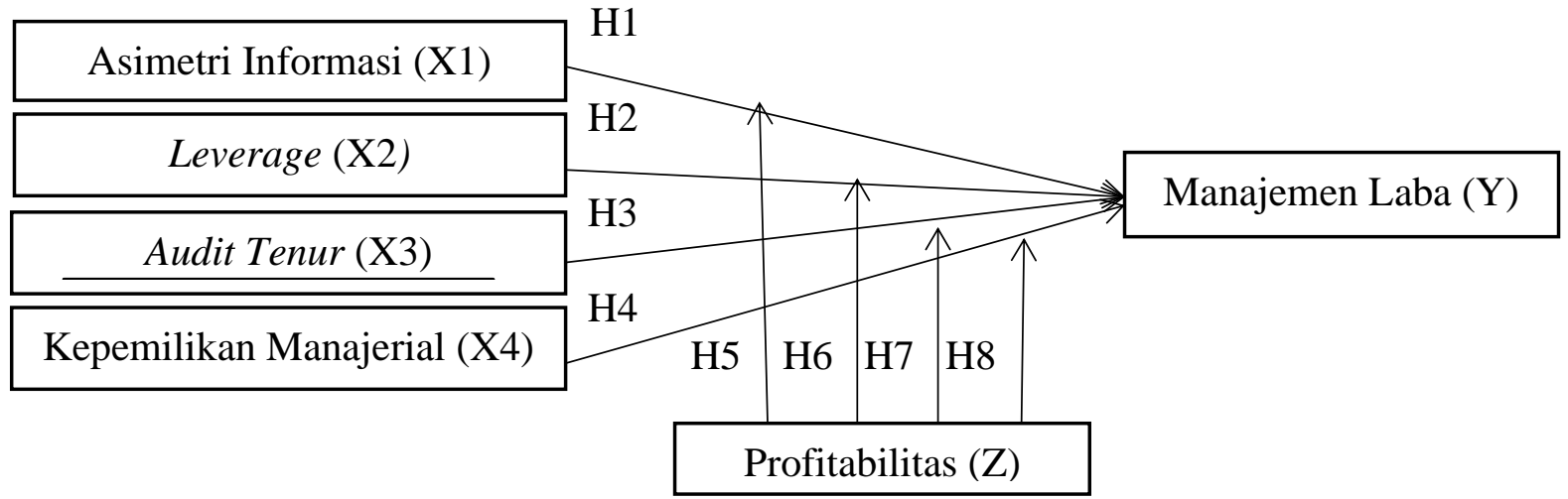

\section{Hipotesis Peneletian}

\section{Gambar 1. Kerangka Konseptual Penelitian}

Hipotesis 1 : Asimetri informasi berpengaruh positif terhadap manajemen laba

Hipotesis 2 : Leverage berpengaruh positif terhadap manajemen laba

Hipotesis 3 : Audit tenure berpengaruh positif terhadap manajemen laba

Hipotesis 4 : Kepemilikan manajerial berpengaruh positif terhadap manajemen laba

Hipotesis 5 : Profitabilitas mampu memoderasi asimetri informasi terhadap manajemen laba

Hipotesis 6 : Profitabilitas mampu memoderasi leverage terhadap manajemen laba

Hipotesis 7 : Profitabilitas mampu memoderasi audit tenure terhadap manajemen laba

Hipotesis 8 : Profitabilitas mampu memoderasi kepemilikan manajerial terhadap manajemen laba

\section{METODE PENELITIAN}

\section{Metode Penelitian}

Penelitian ini meruapakan penelitian assosiatif kausal yaitu penelitian yang bertujuan untuk menganalisis hubungan antara dua variabel atau lebih. Penelitian ini menguji pengaruh asimetri informasi, leverage, audit tenure, kepemilikan manajerial sebagai variabel independen terhadap manajemen laba sebagai variabel dependen dan profitabilitas sebagai variabel moderasi. Populasi dalam penelitian ini adalah perusahaan pertambangan yang terdaftar di Bursa Efek Indonesia periode 2008-2019 yang berjumlah 47 perusahaan. Penelitian ini menggunakan teknik purposive sampling dalam menentukan sampel penelitian. Adapun kriteria dibangun dalam menentukan sampel adalah sebagai berikut :

1. Perusahaan yang tercatat pada Bursa Efek Indonesia berturut-turut selama tahun 20082019.

2. Laporan keuangan yang bermata uang rupiah.

Adapun setelah diberi kriteria maka sampel penelitian ini menjadi 9 perusahaan. Penelitian ini menggunakan data satu tahun maka jumlah observasi yang digunakan adalah sebanyak 108 pengamatan. Data yang digunakan dalam penelitian ini adalah data sekunder dan metode pengumpulan data yaitu studi dokumentasi. Teknik pengumpulan data menggunakan pendekatan structural equation model (SEM) berbasis partial least square (PLS). 


\section{HASIL PENELITIAN DAN PEMBAHASAN}

\section{Hasil Penelitian}

\begin{tabular}{|lr|r|}
\multicolumn{1}{|c}{ Hasil Path Coefficients } & & \multicolumn{2}{c|}{} \\
\hline & Path Coefficients & \multicolumn{2}{c|}{$\begin{array}{c}\text { Sample } \\
\text { Mean }\end{array}$} \\
\hline Asimetri informasi $\rightarrow$ Manajemen Laba & 0,297 & 0,303 \\
\hline Audit Tenure $\rightarrow$ Manajemen Laba & 0,255 & 0,234 \\
\hline Kepemilikan Manajerial $\rightarrow$ Manajemen Laba & 0,252 & 0,236 \\
\hline Leverage $\rightarrow$ Manajemen Laba & $-0,184$ & $-0,185$ \\
\hline
\end{tabular}

Pengaruh variabel independen yang terkuat ditunjukkan dengan pengaruh asimetri informasi terhadap manajemen laba, yaitu sebesar 0,297. Kemudian pengaruh terkuat kedua adalah pengaruh audit tenure terhadap manajemen laba yaitu sebesar 0,255. Pengaruh terkuat ketiga adalah pengaruh kepemilikan manajerial terhadap manajemen laba yaitu sebesar 0,252. Dan pengaruh terkuat terakhir adalah pengaruh leverage terhadap manajemen laba yaitu sebesar 0,184 .

Hasil R-Square

\begin{tabular}{|c|c|}
\hline Keterangan & $R$-Square \\
\hline Manajemen Laba & 0,306 \\
\hline
\end{tabular}

Nilai $R$-Square yang diperoleh dalam model penelitian ini adalah sebesar 0,306 . Perolehan nilai tersebut menjelaskan bahwa variabel independen yaitu asimetri informasi, leverage, audit tenure dan kepemilikan manajerial mampu menjelaskan atau menggambarkan manajemen laba sebesar 0,306 atau 30,6\%. Sedangkan sisanya sebesar $69,4 \%$ lainnya dijelaskan atau digambarkan oleh variabel lain yang tidak digunakan dalam penelitian ini.

\section{Hasil Uji t}

\begin{tabular}{|c|l|r|}
\hline Hipotesis & \multicolumn{1}{|c|}{ Path } & t-Statistics \\
\hline $\mathbf{1}$ & Asimetri Informasi $\rightarrow$ Manajemen Laba & 3,043 \\
\hline $\mathbf{2}$ & Leverage $\rightarrow$ Manajemen Laba & 2,121 \\
\hline $\mathbf{3}$ & Audit Tenure $\rightarrow$ Manajemen Laba & 2,072 \\
\hline $\mathbf{4}$ & Kepemilikan Manajerial $\rightarrow$ Manajemen Laba & 2,161 \\
\hline
\end{tabular}

Asimetri informasi $\left(\mathrm{X}_{1}\right)$ memiliki nilai t-statistik sebesar 3,043 > 1,96 yang artinya asimetri informasi $\left(\mathrm{X}_{1}\right)$ memiliki pengaruh yang signifikan terhadap manajemen laba pada Perusahaan Pertambangan yang terdaftar di Bursa Efek Indonesia. Variabel leverage $\left(\mathrm{X}_{2}\right)$ memiliki nilai tstatistik sebesar 2,121 > 1,96 yang artinya leverage $\left(\mathrm{X}_{2}\right)$ juga memiliki pengaruh yang signifikan terhadap manajemen laba pada Perusahaan Pertambangan yang terdaftar di Bursa Efek Indonesia. Variabel independen lainnya yaitu audit tenure $\left(\mathrm{X}_{3}\right)$ memiliki nilai t-statistik sebesar 2,072 > 1,96 yang artinya audit tenure $\left(\mathrm{X}_{3}\right)$ terbukti memiliki pengaruh yang signifikan terhadap manajemen laba pada Perusahaan Pertambangan yang terdaftar di Bursa Efek Indonesia. Dan terakhir kepemilikan manajerial $\left(\mathrm{X}_{4}\right)$ memiliki nilai t-statistik sebesar 2,161 > 1,96 yang artinya kepemilikan manajerial $\left(\mathrm{X}_{4}\right)$ juga terbukti memiliki pengaruh yang signifikan terhadap manajemen laba pada Perusahaan Pertambangan yang terdaftar di Bursa Efek Indonesia. 


\begin{tabular}{|c|l|r|}
\hline \multicolumn{2}{|c|}{ Hasil Uji interaksi } & t-Statistics \\
\hline Hipotesis & \multicolumn{1}{|c|}{ Path } & 0,519 \\
\hline $\mathbf{5}$ & $\mathrm{X} 1 * \mathrm{Z} \rightarrow$ Manajemen Laba & 2,546 \\
\hline $\mathbf{6}$ & $\mathrm{X} 2 * \mathrm{Z} \rightarrow$ Manajemen Laba & 0,411 \\
\hline $\mathbf{7}$ & $\mathrm{X} 3 * \mathrm{Z} \rightarrow$ Manajemen Laba & 1,308 \\
\hline $\mathbf{8}$ & $\mathrm{X} 4 * \mathrm{Z} \rightarrow$ Manajemen Laba & \\
\hline
\end{tabular}

$\mathrm{X}_{1} * \mathrm{Z}$ yang merupakan interaksi antara profitabilitas dengan asimetri informasi memiliki nilai t-statistik 0,519 yang lebih kecil dari 1,96. Sehingga dapat disimpulkan bahwa profitabilitas tidak dapat memoderasi pengaruh asimetri informasi terhadap manajemen laba. $\mathrm{X}_{2} * \mathrm{Z}$ yang merupakan interaksi antara profitabilitas dengan leverage memiliki nilai t-statistik 2,546 yang lebih besar dari 1,96. Sehingga dapat disimpulkan bahwa profitabilitas dapat memoderasi pengaruh leverage terhadap manajemen laba. $\mathrm{X}_{3} * \mathrm{Z}$ yang merupakan interaksi antara profitabilitas dengan audit tenure memiliki nilai t-statistik 0,411 yang lebih kecil dari 1,96. Sehingga dapat disimpulkan bahwa profitabilitas tidak dapat memoderasi pengaruh audit tenure terhadap manajemen laba. $\mathrm{X}_{4} * \mathrm{Z}$ yang merupakan interaksi antara profitabilitas dengan kepemilikan manajerial memiliki nilai t-statistik 1,308 yang lebih kecil dari 1,96. Sehingga dapat disimpulkan bahwa profitabilitas tidak dapat memoderasi pengaruh kepemilikan manajerial terhadap manajemen laba.

\section{Pengaruh Asimetri Informasi Terhadap manajemen laba}

Hasil dalam penelitian ini juga menunjukkan bahwa asimetri informasi terbukti memiliki pengaruh yang positif dan signifikan terhadap manajemen laba. Hasil yang diperoleh dalam penelitian ini sejalan dengan hasil penelitian yang dilakukan oleh (Desmiyawati, 2009), (Putra et al., 2014), (Restuwulan, 2013) yang melakukan penelitian di perusahaan manufaktur. Ketika asimetri informasi yang dimiliki perusahaan tinggi, maka stakeholders tidak memiliki sumber daya yang cukup, insentif atau akses informasi yang relevan untuk memonitor tindakan para agent (manajemen). Sehingga hal ini akan memberikan peluang kepada manajer untuk melakukan tingakan manajemen laba.

\section{Pengaruh Leverage Terhadap Manajemen Laba}

Hasil dalam penelitian ini justru menunjukkan hal sebaliknya dimana leverage terbukti memiliki pengaruh yang negatif dan signifikan terhadap manajemen laba. Hasil tersebut dikuatkan dengan hasil penelitian yang dilakukan oleh ( Gombola, 2016), Perdana (2012), (Raras Mahiswari, 2014), serta (Zamri et al., 2016). Hal ini disebabkan karena perusahaan dengan leverage yang tinggi akan menyebabkan pihak manajemen perusahaan menjadi lebih sulit dalam membuat prediksi untuk jalannya perusahaan ke masa depan. Selain itu, semakin besar utang yang dimiliki perusahaan maka semakin ketat pula pengawasan yang dilakukan oleh pihak kreditor, sehingga fleksibilitas manajemen untuk melakukan tindakan manajemen laba menjadi semakin berkurang.

\section{Pengaruh Audit Tenure Terhadap Manajemen Laba}

Hasil dalam penelitian menunjukkan bahwa audit tenure terbukti memiliki pengaruh yang positif dan signifikan terhadap manajemen laba. Begitu juga hasil penelitian yang dilakukan oleh (Cahyadi \& Davianti, 2020), (Wijayanti \& Triani, 2020), dan (Virena , 2020). Lamanya audit tenure dapat menyebabkan auditor mengembangkan "hubungan yang lebih nyaman" dan kesetiaan yang kuat atau hubungan emosional dengan klien mereka, sehingga independensi auditor menjadi terancam. 


\section{Pengaruh Kepemilikan Manajerial Terhadap Manajemen Laba}

Hasil dalam penelitian menunjukkan bahwa kepemilikan manajemen terbukti memiliki pengaruh yang positif dan signifikan terhadap manajemen laba. Hal ini didukung oleh hasil penelitian terdahulu yang dilakukan oleh (Dong et al., 2020) dan (Piosik \& Genge, 2020). Kepemilikan seorang manajer akan ikut menentukan kebijakan dan pengambilan keputusan terhadap metode akuntansi yang diterapkan pada perusahaan yang mereka kelola. Presentase tertentu kepemilikan saham oleh pihak manajemen cenderung memengaruhi tindakan manajemen laba.

\section{Profitabilitas dalam Memoderasi Pengaruh Asimetri Informasi Terhadap Manajemen Laba}

Hasil pengujian interaksi dalam penelitian menunjukkan bahwa profitabilitas terbukti tidak mampu memoderasi pengaruh asimetri informasi terhadap manajemen laba. Hal ini disebabkan karena perusahaan yang telah memiliki tingkat profitabilitas yang tinggi umumnya akan cenderung untuk bermain aman dan memilih untuk tidak melakukan manajemen laba.

\section{Profitabilitas dalam Memoderasi Pengaruh Leverage Terhadap Manajemen Laba}

Hasil pengujian interaksi dalam penelitian menunjukkan bahwa profitabilitas terbukti mampu memoderasi pengaruh leverage terhadap manajemen laba. Hasil yang diperoleh dalam penelitian ini sejalan dengan hasil penelitian terdahulu yang dilakukan oleh (Indawati \& Anggraini, 2019). Adanya nilai leverage yang tinggi akan mencerminkan perusahaan tersebut terancam tidak sehat atau bangkrut, sehingga perusahaan tersebut cenderung akan dengan sengaja melakukan manajemen laba agar tidak terjadi fluktuasi yang berlebihan agar tercermin kinerja perusahaan yang baik antara profitabilitas dengan leverage sehingga perusahaan akan tetap dipercaya oleh pihak kreditur.

\section{Profitabilitas dalam Memoderasi Pengaruh Audit Tenure Terhadap Manajemen Laba} Hasil pengujian interaksi dalam penelitian menunjukkan bahwa profitabilitas terbukti tidak mampu memoderasi pengaruh audit tenure terhadap manajemen laba. Hal ini disebabkan karena perusahaan yang memiliki tingkat profitabilitas yang tinggi umumnya cenderung untuk bermain aman dan memilih untuk tidak melakukan manajemen laba. Sehingga profitabilitas yang merupakan rasio keuangan perusahaan ini tidak mampu memoderasi pengaruh dari audit tenure terhadap manajemen laba perusahaan pertambangan.

\section{Profitabilitas dalam Memoderasi Pengaruh Kepemilikan Manajerial Terhadap Manajemen Laba}

Hasil pengujian interaksi dalam penelitian menunjukkan bahwa profitabilitas terbukti tidak mampu memoderasi pengaruh kepemilikan manajerial terhadap manajemen laba. walaupun tingkat kepemilikan manajerial yang dimiliki perusahaan tinggi, dan hal tersebut dapat mendorong pihak manajemen perusahaan untuk menghasilkan tingkat profitabilitas yang lebih baik untuk kepentinganya sebagai investor, bukan berarti pihak manajemen lantas melakukan tindakan manajemen laba. Hal ini juga didorong oleh alasan bahwa perusahaan yang memiliki tingkat profitabilitas yang tinggi umumnya cenderung untuk bermain aman dan tidak melakukan manajemen laba.

\section{KESIMPULAN DAN SARAN}

Berdasarkan hasil pengujian dan pembahasan, maka kesimpulan dalam penelitian ini adalah variabel asimetri informasi, audit tenure, kemepilikan manajerial memiliki pengaruh yang positif dan signifikan terhadap manajemen laba. Namun, variabel leverage memiliki pengaruh 
yang negatif dan signifikan terhadap manajemen laba pada perusahaan pertambangan yang terdaftar di BEI. Hasil dalam penelitian ini menunjukkan bahwa profitabilitas tidak mampu memoderasi asimetri informasi, audit tenure, kepimilkan manajerial terhadap manajemen laba. Namun profitabilitas mampu memoderasi leverage terhadap manajemen laba.

Hasil penelitian ini menyarankan perusahaan pertambangan agar dapat menurunkan tingkat asimetri informasi yang terjadi yang dapat memecah belah investor dengan manajerial, selain itu perusahaan juga diharapkan agar menjaga audit tenure dan kepemilikan agar tingkatannya tidak terlalu tinggi. Karena tingkat manajemen laba juga akan semakin meningkat dengan naiknya audit tenure dan persentase kepemilikan manajerial. Saran yang dapat diberikan pada peneliti selanjutnya adalah diharapkan dapat menggunakan variabel pemoderasi yang lain untuk mengetahui variabel apa saja yang dapat dijadikan sebagai pemoderasi terhadap manajemen laba dan kembali menguji pengaruh variabel lain yang dapat mempengaruhi manajemen laba seperti kualitas audit, ukuran perusahaan, opini audit pada perusahaan sektor pertambangan.

\section{DAFTAR PUSTAKA}

Agustia, D. (2013). Pengaruh Faktor Good Corporate Governance, Free Cash Flow, dan Leverage Terhadap Manajemen Laba. Jurnal Akuntansi Dan Keuangan, 15(1), 27-42. https://doi.org/10.9744/jak.15.1.27-42

Cahyadi, A., \& Davianti, A. (2020). Pengaruh Faktor Internal Dan Eksternal Perusahaan Terhadap Praktik Manajemen Laba Di Perusahaan Publik Sektor Barang Konsumsi Periode 2014-2018. International Journal of Social Science and Business, 4(2), 172-181. https://doi.org/10.23887/ijssb.v4i2.24957

Dechow, Patricia M.Richard G.Sloan, dan A. P. S. (1995). Detecting Earning Management The Accounting Review. 70.

Desmiyawati, N. dan Y. F. (2009). Pengaruh Asimetri Informasi dan Ukuran Perusahaan terhadap Praktik Manajemen Laba Pada Perusahaan Manufaktur yang Terdaftar di Bursa Efek Indonesia. Pekbis Jurnal, 1.1.

Dong, N., Wang, F., Zhang, J., \& Zhou, J. (2020). J . Account . Public Policy Ownership structure and real earnings management : Evidence from China. Journal of Accounting and Public Policy, xxxx, 106733. https://doi.org/10.1016/j.jaccpubpol.2020.106733

Firdaus, I. (2013). Pengaruh Asimetri Informasi dan Capital Adequacy Ratio terhadap Manajemen Laba. Jurnal Akuntansi, 1(1), 1-27. http://ejournal.unp.ac.id/students/index.php/akt/article/view/59

Gideon, S. B. \& B. (2005). Kualitas Laba: StudiPengaruh Mekanisme Corporate Governance danDampak Manajemen Laba dengan MenggunakanAnalisis Jalur. In Simposium Nasional Akuntansi VIII (pp. 172-194).

Indawati, I., \& Anggraini, A. (2019). Profitabilitas Memoderasi Financial Leverage Dan Pertumbuhan Perusahaan Terhadap Perataan Laba. EkoPreneur, 1(1), 31. https://doi.org/10.32493/ekop.v1i1.3669

Jatinungrum. (2000). Analisis Faktor-Faktor yang Berpengaruh Terhadap Perataan Penghasilan Bersih/Laba pada Perusahaan yang Terdaftar di BEJ. E-Journal S1 Akuntansi, 2, 145-155.

Michael C. JENSEN and William H. Meckling. (1976). THEORY OF THE FIRM: MANAGERIAL BEHAVIOR, AGENCY COSTS AND OWNERSHIP STRUCTURE. Journal of Financial Economics, 3, 305-360.

Michael J.Gombola. (2016). The effect of leverage and liquidity on earnings and capital management: Evidence from U.S. commercial banks. International Review of Economics \& Finance, 43, 35-58. 
Nugroho. (2011). Pengaruh Struktur Kepemilikan dan Leverage Terhadap Earning Management yang Melakukan IPO di Bursa Efek Indonesia. Universitas Diponegoro.

Perusahaan, P. U., Gunawan, K., Darmawan, A. S., \& Purnamawati, I. G. A. (2015). LEVERAGE TERHADAP MANAJEMEN LABA PADA PERUSAHAAN MANUFAKTUR YANG TERDAFTAR DI BURSA EFEK INDONESIA ( BEI ). 03(01).

Piosik, A., \& Genge, E. (2020). Earnings management prior to mergers and acquisitions: The role of acquirers' ownership structures. Evidence from Poland. Procedia Computer Science, 176, 1299-1311. https://doi.org/10.1016/j.procs.2020.09.139

Putra, P. A., Sinarwati, N. K., Ari, N., \& Darmawan, S. (2014). Pada Perusahaan Manufaktur Yang Terdaftar Di Bursa Efek Indonesia ( Bei ). 1(1).

Raras Mahiswari, P. I. N. (2014). Pengaruh Mekanisme Corporate Governance, Ukuran Perusahaan dan Leverage Terhadap Manajemen Laba dan Kinerja Keuangan. Jurnal Ekonomi Dan Bisnis, 17. https://doi.org/https://doi.org/10.24914/jeb.v17i1.237

Ratna Candra Sari, Z. (2006). KEINFORMATIFAN LABA DI PASAR OBLIGASI DAN SAHAM: UJI LIQUIDATION OPTION HYPOTHESIS. SIMPOSIUM NASIONAL AKUNTANSI 9 PADANG.

Restuwulan. (2013). Pengaruh Asimetri Informasi dan Ukuran Perusahaan Terhadap Manajemen Laba. Universitas Widyatama.

Scott, W. R. (2009). Financial Accounting Theory (Fifth Edit). Canada Prentice Hall.

Virena Gita Hapsari. (2020). PENGARUH GOOD CORPORATE GOVERNANCE, UKURAN KAP, DAN AUDIT TENURE TERHADAP MANAJEMEN LABA (Studi pada Perusahaan BUMN yang Terdaftar di Bursa Efek Indonesia pada Tahun 2014-2018) [Universitas Pendidikan Indonesia]. http://repository.upi.edu/

Wijayanti. (2010). Analisis Hubungan Auditor-Klien. Faktor-faktor yang Mempengaruhi Auditor Switching di Indonesia. undip.

Wijayanti, D. E., \& Triani, N. N. A. (2020). Pengaruh Leverage, Pertumbuhan Perusahaan, Audit Tanure, Dan Opini Audit Terhadap Manajemen Laba (Studi Pada Perusahaan Pertambangan Yang Terdaftar Di Bursa Efek Indonesia Tahun 2013-2017). Jurnal Akuntansi Unesa, 8(3), 1-9.

Zamri, N. A., Purwati, A. S., \& Sudjono, S. (2016). Pengaruh Rasio Profitabilitas dan Leverage Terhadap Earnings Per Share (EPS) (Studi Empiris Pada Perusahaan Manufaktur Yang Terdaftar Di Bursa Efek Indonesia Tahun 2012-2015). Al-Tijary, 1(2), 151-166. https://doi.org/10.21093/at.v1i2.532 